\title{
Specifika místních vodních zdrojů při zásobování obyvatelstva pitnou vodou
}

\section{JOSEF V. DATEL, ANNA HRABÁNKOVÁ}

Klíčová slova: pitná voda - malé vodovody - jakost vody - malé obce

\section{SOUHRN}

Článek představuje "Metodiku komplexního řizení malých vodních zdrojů pro optimální zajištění jakosti pitné vody za běžných i mimořádných situací" [10], která je hlavním výsledkem výzkumného projektu podpořeného Technologickou agenturou ČR (TA 02020184). Jakost pitné vody místních zdrojů ve venkovských oblastech je podle údajů Státního zdravotního ústavu dlouhodobě horší než pitná voda dodávaná většími vodárenskými soustavami. Zpracovaná metodika zohledňuje specifika managementu malých vodních zdrojů za účelem dosažení dobrého technického stavu vodního zdroje a zajištění jeho optimálního provozu a ochrany. Hlavní součástí metodiky je pasportizační formulář, shromaždující všechny potřebné informace o vodním zdroji. Druhá část metodiky zahrnuje postupy odborného vyhodnocení shromážděných dat a návrh opatření ke zlepšení stavu. Závěrečná část se zabývá nouzovým zásobováním pitnou vodou na úrovni malé obce.

\section{ÚVOD}

Zásobování kvalitní pitnou vodou patří k současnému standardu evropské civilizace. Česká republika dlouhodobě přispívá k vysoké úrovni ochrany zdraví obyvatelstva dodávkami zdravotně nezávadné pitné vody. Jakost pitné vody dodávané v malých obcích s vlastními vodními zdroji je ale dlouhodobě méně vyhovující než ve velkých distribučních sítích a v nejdůležitějších ukazatelích nejvyšších mezních hodnot se v posledních letech celkově dále zhoršuje [1, 2].

Management malých vodních zdrojů (s důrazem na obce do 1000 obyvatel s vlastními místními zdroji vody a případně malé vodárenské operátory) má svá specifika a současná legislativní, technická i právní řešení většinou odrážejí situaci velkých sídel a velkých vodárenských společností [3]. Ty disponují širokou škálou odborníků, technických zařízení, mají možnost soustředění finančních prostředků, legislativa jim ukládá mnohem častější četnost vzorkování, takže mohou rychleji zareagovat na prípadné problémy atd.

Odrazem tohoto stavu je skutečnost, že $v$ menších obcích jsou mnohem častěji porušovány legislativní limity pro pitnou vodu a obyvatelstvo venkova tak má v některých územích méně kvalitní pitnou vodu. Problematická situace u malých zdrojů zásobování pitnou vodou je výsledkem kombinovaného působení řady př́čin jak historických, tak současných, jak je komplexně a podrobně uvádějí předchozí publikace $[4,5]$. Některé z nich Ize zdůraznit i zde:

- Nižší úroveň ochrany malých zdrojů - ochranná pásma se podle zákona O vodách č. 254/2001 Sb. stanovují povinně jen pro zdroje s odběrem nad $10000 \mathrm{~m}^{3}$ za rok.
- Významné nedostatky a neúplnost v evidencích malých odběrů (odebíraná množství podle vyhlášky č. 431/2001 Sb., i jakost surové vody podle vyhlášky č. 428/2001 Sb.) ukazují, že pro některé malé obce je náročné nejen technické zajištění vodárenských odběrů, ale i administrativa kolem provozování místního vodovodu.

— Významně nižší četnost rozborů surové vody (podle vyhlášky č. 428/2001 Sb.), v nejnižší kategorii do 500 zásobovaných obyvatel se jedná pouze o jediný krácený monitorovací rozbor ročně. U vyrobené pitné vody jde o 2 krácené monitorovací rozbory ročně a 1 úplný rozbor 1x za dva roky. Pravděpodobnost detekce občasných problematických stavů je tedy velmi nízká.

- Neexistuji žádné legislativní požadavky na pravidelné kontroly stavu klí̌ových součástí vodárenského systému zásobování pitnou vodou, zhodnocení potenciálních rizik a provedení nápravných opatření. Orgány hygienické služby zaměrují svoji pozornost především na vyrobenou pitnou vodu. Kontrola a údržba vlastních jímacích objektů a dalších technických zařizení vodovodního systému (řady, vodojemy aj.) zůstává na provozovateli a jeho odpovědném prístupu. Vyhlášená ochranná pásma a stanovená omezující opatření v nich se podle zkušeností autorů kontroluji u malých zdrojů jen sporadicky, vodoprávní úřady své kompetence v tomto směru príliš často nevyužívají.

- Malé zdroje mají obvykle jen velmi jednoduchou technologii úpravy (někdy pouze desinfekci), a někdy ani není správně obsluhována, takže často technologie úpravy a desinfekce vody nedosahuje optimální účinnosti.

- Nedostatek odborných znalostí a odborného zázemí na straně provozovatele. Odpovědné osoby malých vodovodů často nemají ani potřebné vzdělání, ani znalosti. Jsou dokonce prípady (např. u gravitačních zdrojů), kdy provozovatel nezná přesné umístění jímacích zárezů, pramenních jímek apod., a jak se do nich dostat.

\section{MALÉ VODNÍ ZDROJE V PODMÍNKÁCH ČESKÉ REPUBLIKY}

V ČR žije podle údajů ČSú (2012) 1800000 lidí v 4846 obcích menších než 1000 obyvatel. Vodovody jsou evidovány v celkem 5036 obcích, z nichž 87 \% jsou malé obce do 2000 obyvatel. Přibližně 1200 obcí (vesměs obce malé a nejmenší) nemá veřejný vodovod, obyvatelé jsou tedy odkázáni na individuální zdroje, prípadně obecní studny [6]. Odhadem polovina z těchto obcí je odkázána na místní vodní zdroje nebo individuální domovní studny svých obyvatel; jedná se vesměs o vodu z podzemních zdrojů. V České republice je tak cca 1 mil. obyvatel zásobovaných pitnou vodou z malých vodovodů, veřejných a domovních studní. Jedná se o zásobování menších obcí, které nejsou a mnohdy ani do budoucna nebudou moci (pro odlehlost, obtižnost prístupu, horský terén apod.) být napojeny na větší veřejné vodovody. Zajištění jakosti 
těchto zdrojů je vzhledem k jejich roztroušenosti mnohdy problematické. Pro účely projektu byla na celostátní úrovni provedena podrobná analýza odběrů podzemních vod pro pitné účely z hlediska jejich lokalizace a velikosti, aby byla získána co nejlepší představa o rozsahu této záležitosti a z toho vyplývající důležitost a náročnost řešení.

Podle zákona o vodovodech a kanalizacích č. 274/2001 Sb. je ustanoveno celkem 2130 vodárenských operátorů (formálně pro zabezpečení nouzového zásobování, prakticky se ale kryjí s operátory běžného zásobování), z nichž přes 95 \% se týká opět jen malých obcí (pouhých cca 100 největších operátorů pokrývá podle zdrojů z Ministerstva zemědělství až $80 \%$ obyvatelstva soustředěných v největších sídlech). Současný stav zásobování vodou venkova se tak vyznačuje roztříštěností, nekoncepčností a nekoordinací.

Zpracovanémetodice (zdůvodu komplexního pohledu nazásobovánípitnou vodou) předchází metodický materiál s názvem Metodika pro zajištění bezpečného zásobování pitnou vodou pro jednoduché vodárenské systémy [3], která pokrývá problematiku technického systému vodovodního zásobování obyvatelstva pitnou vodou. Metodika zpracovaná ve spolupráci Výzkumného ústavu vodohospodářského TGM a Státního zdravotního ústavu primárně reflektuje zdravotně-hygienický pohled na stav a rizika vodovodně-technické části komplexního systému zásobování pitnou vodou, počínaje odběrem surové vody z prírodního prostředí. Vzájemný vztah obou metodik zobrazuje schéma na obr.1. Popis metodických př́istupů a způsobu řešení obsahuje [6,7].

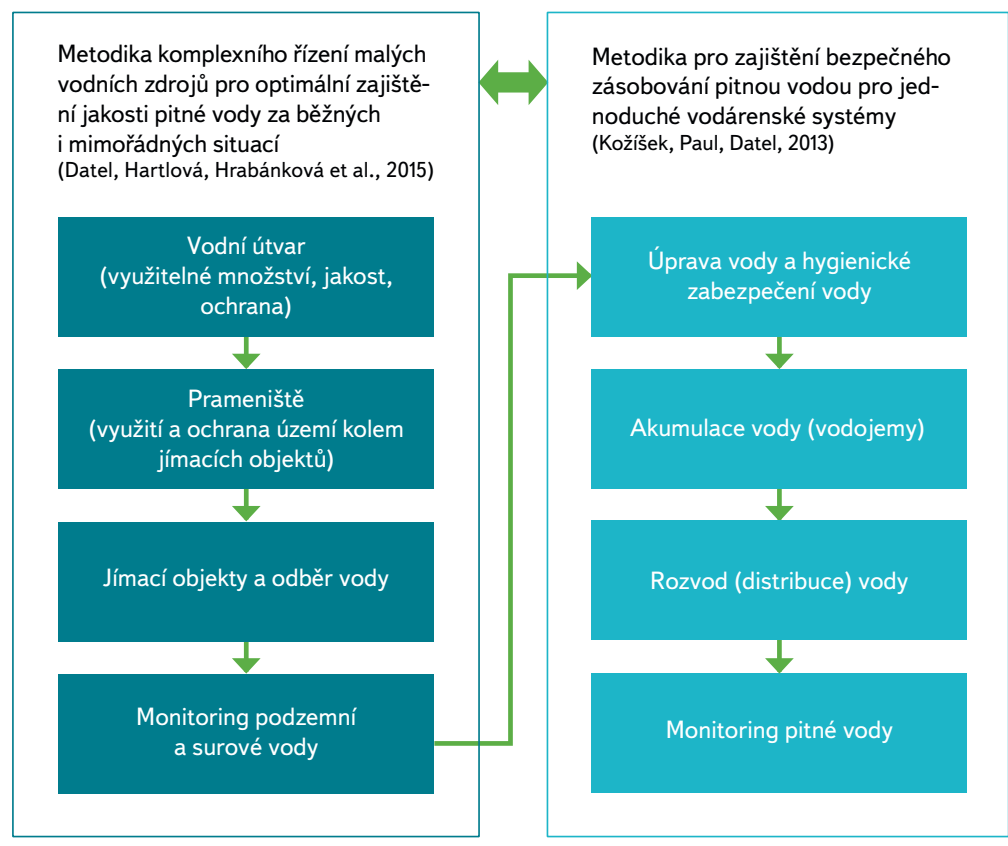

Obr. 1. Schéma vztahu obou metodik a zařazení hlavních částí komplexního vodáren-

ského systému do obou metodik [10]

Fig. 1. Chart showing relation between two methodologies and inclusion of main parts of a complex water supply system to the two methodologies [10]

Při rozboru situace se také vycházelo z hlášení odběratelů odběrů (podle vyhlášky č. 431/2001 Sb. „O obsahu vodní bilance“), kteří mají povinnost předávat údaje př́slušným správcům povodí, pokud je odběr větší než 6000 m³ v kalendářním roce nebo měsíční odběr přesahuje $500 \mathrm{~m}^{3}$. Do hodnocení byly zařazeny odběry využívané pro pitné účely zařazené podle odvětvové klasifikace ekonomických činností OKEČ a také nové klasifikace CZ-NACE. K datu zahájení projektu, kdy byla provedena analýza (tedy 2012), bylo evidováno pro účely vodní bilance na území ČR 2685 odběrů vody (vesměs šlo o odběry podzemní vody), které se využívají pro pitné účely a jejichž velikost nepřekračuje $2 \mathrm{l} / \mathrm{s}$.
Tyto malé odběry podzemní vody byly rozděleny do čtyř kategorií. Největší množství těchto odběrů má velikost do 0,5 I/s (52\%), v kategorii od 0,5 do $1 \mathrm{l} / \mathrm{s}$ je $27,3 \%$ odběrů, od 1 do 1,5 l/s je 13,5 \% odběrů a v poslední kategorii od 1,5 do $2 \mathrm{l} / \mathrm{s}$ je 7,2 \% odběrů podzemních vod. Je nutné si uvědomit, že počet nejmenších odběrů bude ve skutečnosti ještě mnohem vyšší, jen nejsou úředně vykazovány. Část odběrů je hlášena krajským úřadưm a př́slušnému správci povodí v rámci vyhlášky č. 428/2001 Sb. a jsou obsaženy v interní databázi webové aplikace VúV TGM. Z geografického rozložení malých odběrů vyplývá, že se ve velké míre vyskytují v horských oblastech a také $v$ místech mimo velké městské aglomerace. Některé z nich leží v chráněných oblastech přirozené akumulace vod nebo ve zranitelných oblastech, což může částečně pomáhat zajištovat jejich kvalitu z obecného hlediska, nicméně to nic nevypovídá o skutečné kvalitě jímané vody.

Z provedené analýzy je možné učinit dílčí závěr, že evidence podle vyhlášky 431/2001 Sb. nepokrývá ani zdaleka všechny malé zdroje pitné vody, protože se povinnost evidence nevztahuje na zdroje nejmenší (odběr menší než $6000 \mathrm{~m}^{3}$ za rok, tzn. cca 0,2l/s). Zdroje s vydatností pod 0,2l/s však mohou zásobovat sídla nebo jejich části až do 150-200 obyvatel. Z toho vyplývá, že nezanedbatelná část obyvatelstva venkovských oblastí je zásobována vodou z tzv. místních vodovodů, které nejsou evidovány a jejichž jakost je sledována v neznámém rozsahu, nesystematicky, prakticky na úrovni individuálních zdrojů vody (domovní studny), kde jakost odebírané vody je plně na odpovědnosti uživatele studny.

\section{ANALÝZA SITUACE V PILOTNÍM OKRESE RAKOVNÍK}

Za účelem přesnějšího odhadu míry podchycení malých vodních zdrojů ve výše zmíněné databázi byla podrobně prověřena situace $v$ měřítku jednoho okresu. Cíleně byl vybrán okres Rakovník, protože hydrologická bilance je zde velmi napjatá, jsou zde problémy s vodními zdroji povrchových i podzemních vod. Byl zde proto předpoklad (který se bohužel nepotvrdil), že evidence odběrů bude na mnohem lepší úrovni než v oblastech, kde je vody dostatek.

Na území okresu Rakovník bylo zjištěno celkem 58 odběrů podzemních vod určených pro zásobování obyvatelstva pitnou vodou [8-10], viz obr. 2. Tyto zdroje jsou provozovány jednak vodárenskými společnostmi (převážně RAVOS, Vodárny Kladno Mělník aj.) a také obcemi, na jejichž území se zdroj nachází. V převážné části je na ně napojen veřejný vodovod, v osmi prípadech je zdroj označen za místní, popř. záložní a je využíván pro místní vodovod. Pro účely bilance je hlášeno podniku Povodí VItavy 27 odběrů. Je to dáno hlavně ohlašovací povinností podle vyhlášky o bilanci, která se týká odběrů větších než $6000 \mathrm{~m}^{3}$ v kalendářním roce nebo měsičního odběru většího než $500 \mathrm{~m}^{3}$. Z daného porovnání vyplývá, že 31 (převážně nejmenších) zdrojů není správci povodí evidována, tedy více než polovina všech zdrojů. Je pravděpodobné, že odběry u těchto neevidovaných zdrojů většinou nepřesáhnou hranici $6000 \mathrm{~m}^{3}$ ročně, a uvedené hodnoty znamenají využitelnou vydatnost nebo povolený odběr.

Z 58 provozovaných zdrojů jich samy obce provozují 27 , tedy $47 \%$. Toto je cílová skupina řešeného projektu, protože jde především o malé obce, které nedisponují potřebnými odborníky, znalostmi ani technickým zázemím k provozování svého vodovodu, někdy není ani potřebný zájem z vedení obce.

Z daných informací lze učinit závěr, že nejmenší využívané vodní zdroje jsou nejen často neevidované (protože mají odběr pod stanovenou hodnotou, takže není povinnost evidence), ale i nesystematicky spravované velmi omezenými možnostmi těch nejmenších obcí. Jejich množství celostátně odhadujeme na úrovni kolem 40 \% počtu evidovaných odběrů, v odlehlých pohraničních oblastech to může být i více, naopak $v$ urbanizovaných oblastech s oblastními a skupinovými vodovody nebudou tvořit významnou skupinu. Jde tedy cca o 1000 odběrných míst v ČR, kterých se tato metodika týká. 


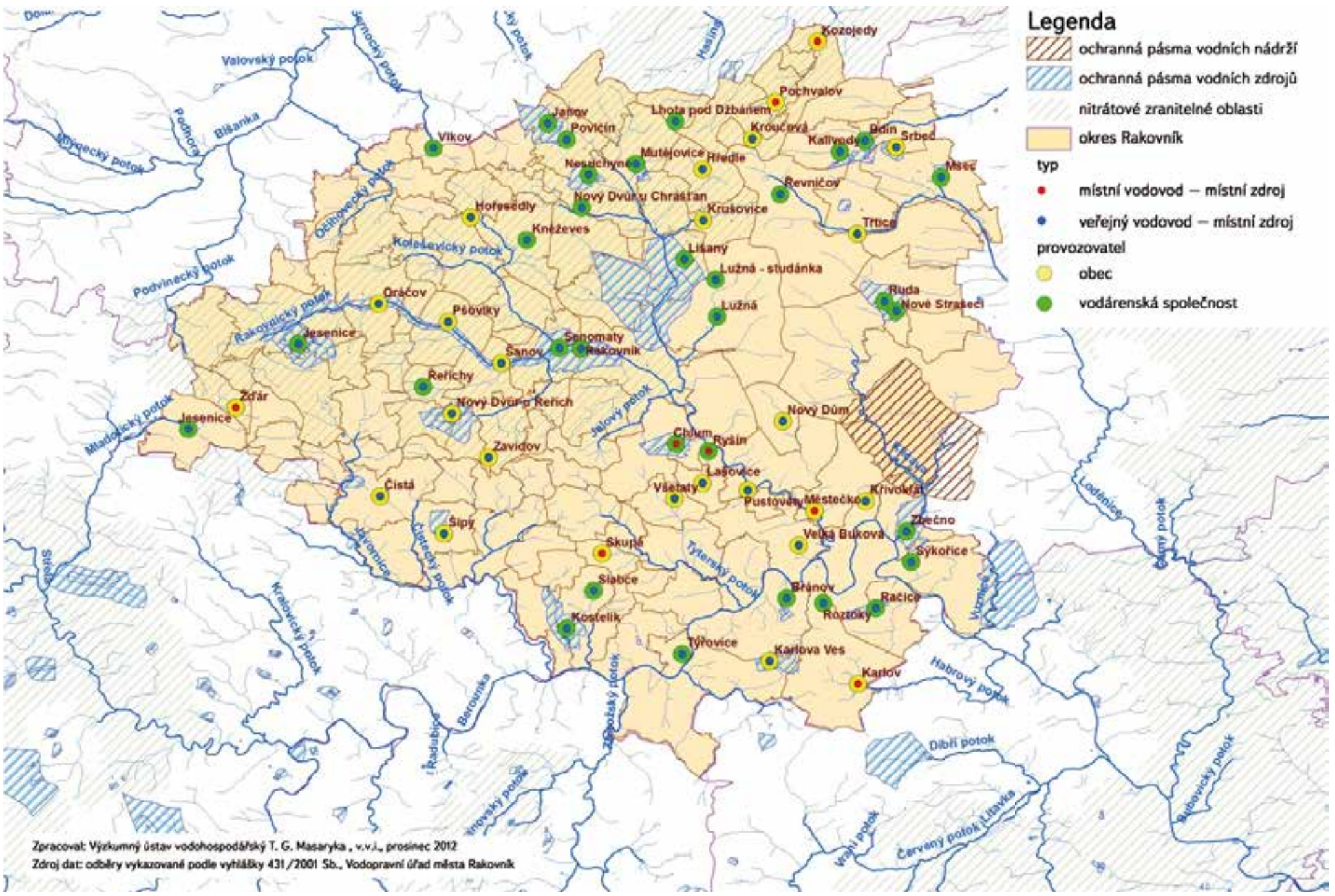

Obr. 2. Odběry pitné vody v okrese Rakovník s uvedením typu vodovodu a provozovatele [10]

Fig. 2. Abstraction of drinking water in the district Rakovnik specifying a water supply system and an operator [10]

\section{PLÁNY BEZPEČNÉHO ZÁSOBOVÁNÍ VODOU (WATER SAFETY PLANS) PRO MÍSTNÍ VODOVODNÍ SYSTÉMY}

Z hlediska zabezpečenosti jakosti vody existuje jak v ČR, tak v jiných zemích EU zajímavá, varovná a výrazná korelace mezi mírou překročení měrných hodnot a velikostí zásobované oblasti. Zatímco u největších oblastí nalézáme nedodržení limitů zdravotně závažných ukazatelů (s nejvyšší mezní hodnotou - NMH) jen u asi 0,02\% stanovení, u nejmenších oblastí je to asi $1 \%$ vzorků. U ukazatelů s mezní hodnotou $(\mathrm{MH})$, které se vztahují především k ovlivnění organoleptických vlastností vody, ale do určité míry mají také zdravotní význam, je pak rozdíl ještě větší: u velkých oblastí byla četnost nedodržení MH 0,5-0,8 \%, u malých oblastí okolo $3 \%[1,3]$.

Ještě více vynikne kritická situace u malých zdrojů tehdy, podíváme-li se na vodovody, u kterých byla udělena nějaká výjimka. Ze 124 veřejných vodovodů, na které byly v roce 2012 uděleny v ČR výjimky z nejvyšších mezních hodnot, bylo plných 114 malých vodovodů zásobujících méně než 1000 obyvatel [3].
Přístup na základě analýzy rizik a kritických kontrolních bodů, který platí pro výrobce potravin na základě nařizení EP a Rady č. 852/2004 (ES), je v současné době postupně zaváděn i pro výrobce pitné vody. Postup známý pod názvem "water safety plans" prosazuje také Světová zdravotnická organizace a Mezinárodníasociace provodu (IWA) a u nás Státnízdravotní ústav. Publikace [3] obsahuje mimo jiné podrobnou metodiku zpracování plánu pro zajištění bezpečného zásobování pitnou vodou, speciálně rozpracovanou pro prostředí malých vodárenských systémů v českém jazyce.

\section{JAK ZLEPŠIT ÚROVEŇ ZÁSOBOVÁNÍ VODOU NA ÚROVNI MALÉ OBCE S MÍSTNÍMI VODNÍMI ZDROJI?}

Existuje několik nutných předpokladů, jejichž splnění se předpokládá, pokud se má v malých vodárenských systémech dosáhnout zásobování kvalitní pitnou vodou [10]: 
- Vedení obce si musí být vědomo zásadní důležitosti dostatku dobré pitné vody pro rozvoj obce a spokojenost svého obyvatelstva.

- Musí být určen konkrétní pracovník, který bude osobně odpovídat za stav obecního vodovodu, a musí disponovat podporou vedení obce.

- Vedení obce si musí být vědomo, že dobrý stav zdrojů vody, jejich zajištění, ochrana a technický stav vodovodního systému něco stojí - konkrétní finanční prostředky.

- Musí být správně stanovena cena vody, zahrnující všechny náklady spojené s provozováním vodovodu a jímacího objektu.

- Nezanedbatelnou výhodou je dobrá a účinná úroveň spolupráce vedení malé obce s př́slušnými orgány státní správy (vodoprávní úřad, hygienická služba), které mohou být zdrojem cenných metodických a administrativních informací a rad pro danou obec.

Z metodického pohledu musí provozovatel malého vodárenského systému zajistit čtyři základní okruhy činností:

- pasportizace a doplnění všech potřebných údajů o vodním zdroji, jímacím objektu a vodovodním systému;

- kontrola zabezpečenosti množství a jakosti jímané a pitné vody, její úpravy a distribuce, zhodnocení stupně zranitelnosti vodního zdroje a potřebné úrovně jeho ochrany, identifikace rizik a nedostatků;

— návrh opatření ke zlepšení situace a jejich postupná realizace v podmínkách malé obce;

— zásobování vodou v mimořádných a nouzových situacích.

\section{Pasportizace údajů o využívaném vodním zdroji}

Shromáždění všech dostupných údajů a dat o využívaném vodním zdroji je činnost, kterou je do značné míry schopen zajistit malý provozovatel vodovodu svými vlastními silami. Pasportizační formulář se skládá z celkem 51 okruhů otázek, které pokrývají všechny potřebné relevantní informace o využívaném vodním zdroji.

\section{Jde o následující okruhy dat (obr. 3):}

A. Informace o jímacím objektu (studna, pramenní jímka, jímací zářez apod.), provedených průzkumech a technických pracích, včetně zaměření objektů a jejich zákresu v mapě ( 9 otázek);

B. Veškerá technická, odborná a správní dokumentace (odborné zprávy, správní rozhodnutí, povolení a stanoviska, technické projekty, vyjádření, korespondence aj.) a další související podklady (5 otázek);

C. Údaje o zajištovaném monitoringu podle požadavků platných předpisů, především vyhlášky č. 428/2001 Sb., popř. 431/2001 Sb., údaje o množství a jakosti jímané surové a vyrobené pitné vody, včetně používané správné metodiky vzorkování (5 otázek);

D. Ochranná pásma vodního zdroje a omezující opatření v nich, včetně identifikace majitelů dotčených pozemků a úrovně spolupráce s nimi (6 otázek);

E. Zranitelnost a ochrana území kolem jímacích objektů, identifikace možných zdrojů znečištění a dalších potenciálně rizikových antropogenních aktivit v okolí (14 otázek);
F. Vliv povodňové situace (kvantitativní i kvalitativní), včetně bleskových povodní, na stav a využívání jímacího objektu a vodního zdroje (útvaru) (6 otázek);

G. Vliv déletrvajícího období sucha (kvantitativní i kvalitativní) na stav a využívání jímacího objektu a vodního zdroje (útvaru), včetně analýzy dlouhodobějších trendů (6 otázek).

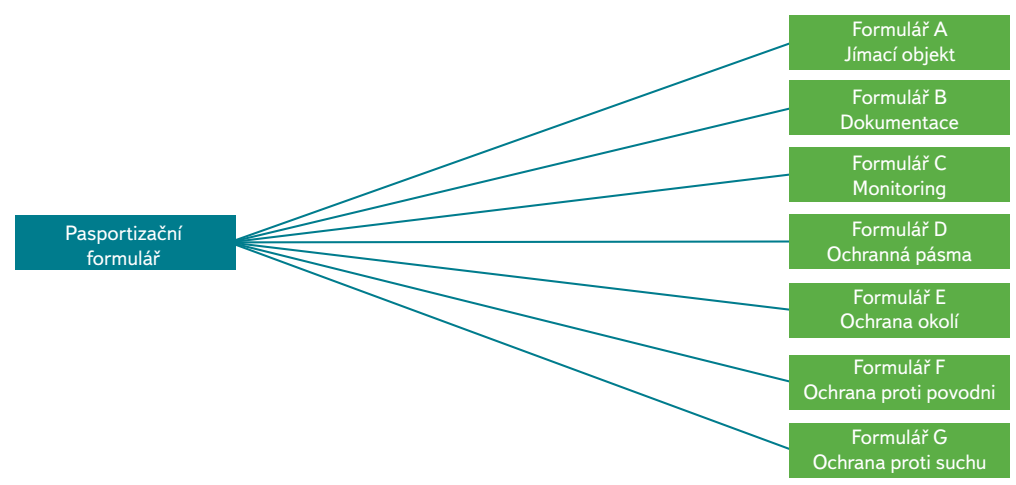

Obr. 3. Struktura formuláře s údaji o využívaném vodním zdroji, které jsou rozdělené do sedmi částí [10]

Fig. 3. Structure of the form with data of a used water resource, which are divided into 7 sections [10]

V rámci „water safety plans“ [3] dále proběhne analýza vlastního vodárenského systému od úpravy, pres akumulaci až po distribuci vyrobené pitné vody obyvatelstvu.

\section{Zhodnocení zabezpečenosti množství a jakosti jímané vody}

$\checkmark$ podstatě se jedná o odborné zhodnocení shromážděných dat v předchozím kroku. Jde o specializovanou odbornou činnost, která už nemůže být provedena na úrovni malé obce, ale následující okruhy prací a problémů musí být posouzeny příslušnými odborníky (odborně způsobilý hydrogeolog, vodohospodář, chemik, hygienik apod.):

- Celkové zhodnocení stavu vodního zdroje a jímacích objektů;

- Zhodnocení stupně zabezpečenosti jakosti a množství jímané vody;

- Zhodnocení ochrany a zranitelnosti vodního zdroje a jímacích objektů;

- Zhodnocení technického stavu vlastního vodovodního systému;

- Identifikace nedostatků a nejistot $v$ celkové zabezpečenosti zásobování obyvatelstva pitnou vodou.

\section{Návrh opatření ke zlepšení situace}

Tato část metodiky je velmi závislá na odborné erudici a zkušenostech oslovených odborníků, jde o jejich hlavní vklad a pomoc obci. Jedná se o stěžejní část metodického přístupu, kde se zúročí náročnost předchozích dvou kroků. Návrh možností zlepšení situace v zásobování obyvatelstva mưže pokrývat následující směry:

- ř́zení a organizaci odběru;

- dokumentaci prací;

- technickou konstrukci jímacích objektů;

- zajištění potřebné ochrany vodního zdroje;

— správný rozsah monitoringu množství a jakosti jímané vody;

— zvýšení odolnosti vodního zdroje proti hrozícím rizikům;

- nastavení účinného kontrolního systému, zahrnujicího i možnosti externí pomoci $s$ rešením budoucích problémů, včetně účinné spolupráce s vodoprávními orgány. 
Naprostou klíčovou součástí výše uvedených návrhů je jejich vyhodnocení z hlediska náročnosti těchto kroků (technické, finanční, personální, odborné) a jejich prioritnosti. Technický způsob realizovatelnosti a stanovení doporučeného pořadí uskutečňování musí respektovat omezené zdroje (hodnocení realizovatelnosti v podmínkách malé obce).

\section{Nouzové zásobování vodou v malých obcích}

V oblasti nouzového zásobování vodou v mimořádné situaci je stav na úrovni malých obcí značně neuspokojivý. Většina malých obcí spoléhá na základě analýzy dat z PRVKÚK (krajských plánů rozvoje vodovodů a kanalizací) na dovoz vody cisternami, prípadně balenou vodu, a to prostřednictvím Integrovaného záchranného systému, nouzových vodárenských operátorů, potažmo Služby nouzového zásobování vodou, tedy na vnější pomoc v rámci krizového řízení.

Je nutno ale zdůraznit, že je všestranně výhodné (pro obec, místní obyvatele i pro stát), když bude obec disponovat svými vlastními zdroji pro nouzové zásobování svých obyvatel, pokud prírodní podmínky katastru obce takovéto rešení dovolí. Výhodnost mít svůj vlastní zdroj vody pro rưzné mimořádné situace vyplývá ze tří aspektů $[9,10]$ :

- aspekt solidarity - pokud má obec možnost mít svůj vlastní vodní zdroj, není solidární spoléhat se na pomoc zvenku, aby se integrovaný záchranný systém (jehož možnosti budou vždy omezené) mohl soustředit na pomoc opravdu potřebným;
- aspekt subsidiarity - nejefektivnější rozhodnutí jsou činěny na nejnižší možné úrovni, v tomto prípadě na úrovni obce, protože zde jsou nejlepší informace o skutečných potřebách obyvatelstva, a nehrozí proto ani nebezpečí plýtvání zdroji (např. zbytečně velkým rozsahem pomoci), ani přehlédnutí oprávněných potřeb ( $v$ důsledku pozdní nebo nedostatečné pomoci);

- aspekt lepšího komfortu pro obyvatelstvo - místní zdroj vody může být obyvatelstvu k dispozici rychleji, může poskytnout větší množství vody a často i lepší kvality, než při spoléhání se na pomoc zvenčí. Jde o aspekt důležitý zvláště pro odlehlé a malé obce $v$ prípadě vzniku mimořádné situace většího rozsahu - v takovém prípadě stát bude postupně zasahovat podle důležitosti, počtu obyvatelstva apod. a hrozí tak reálná možnost výrazného zpoždění potřebné pomoci.

Metodika identifikovala prioritní rizika s větší pravděpodobností výskytu s ohledem na současné poměry a podmínky $v$ rámci ČR pro malé vodní zdroje. Jde o stav povodňové situace, déletrvajícího sucha a ekologické havárie v blízkosti vodního zdroje.

$\checkmark$ katastru príslušné obce a blízkém dostupném okolí by měla proběhnout $v$ předstihu před vznikem mimořádné situace pasportizace existujících dalších objektů podzemních vod (vedle jímacího objektu pro zásobování vodou za běžných podmínek) podle jejich využitelnosti v závislosti na typu hrozícího rizika. Pasportizace by zahrnovala studny, prameny, vrty různého původu, výskyty důlních, drenážních a dalších vod v blízkosti obce apod.

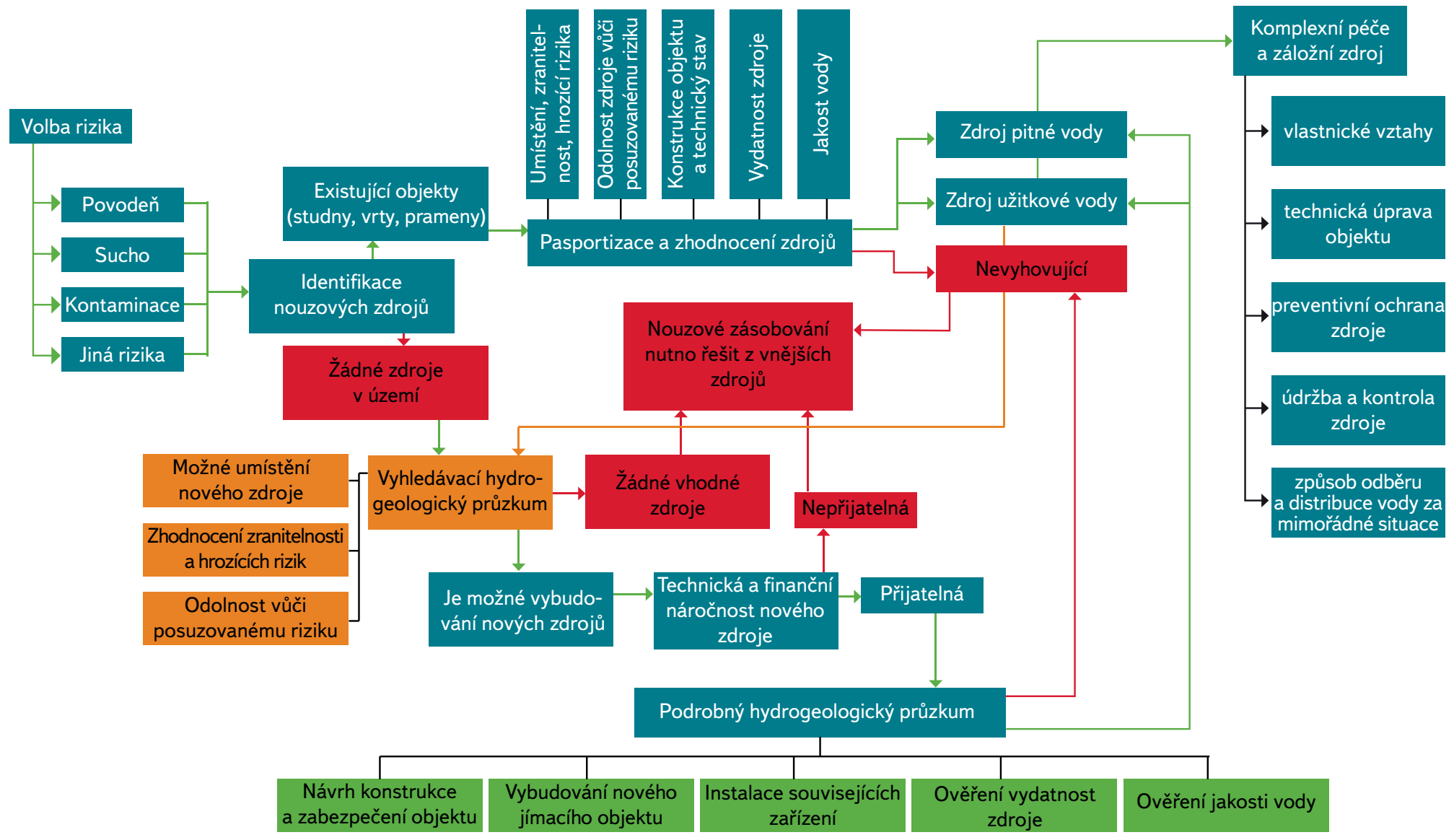

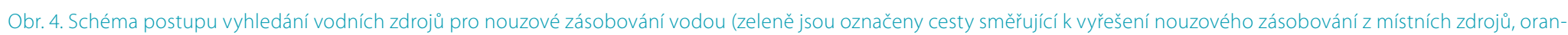
žově jsou označeny cesty hledající řešení problémů a červeně problémy a překážky neumožňující zajištění nouzového zásobování vodou na lokální úrovni) [10]

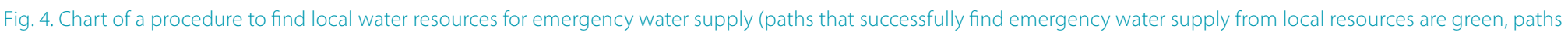
seeking solutions to problems are marked in orange, problems, and obstacles not providing water supplies at the local level are marked in red) [10] 
V prípadě, že vhodné existující zdroje pro nouzové zásobování pitnou či užitkovou vodou vyhovující jakosti, dostatečné vydatnosti a odolnosti proti danému riziku nebudou nalezeny, je možné se pokusit najít zdroje nové na základě vyhledávacího hydrogeologického průzkumu. Ten by mohl být následován podrobnou etapou průzkumu (pokud by byla přijatelná technická a finanční náročnost vybudování nového zdroje), v jehož rámci by se potřebné záložní zdroje již prímo vybudovaly. Následně by pak bylo nutné zajistit průběžnou dlouhotrvající péči a údržbu o tyto záložní zdroje, aby byly v prípadě odstavení běžných zdrojů schopny rychlého zprovoznění (technická úprava objektu, zajištění ochrany okolí, pravidelná kontrola technického stavu, vyřešení způsobu odběru vody a distribuce v mimořádné situaci atd.).

Komplexní postup řešení nouzového zásobování vodou na úrovni malé obce zobrazuje schéma na obr. 4.

K metodice je přiloženo i doporučení Státního zdravotního ústavu z 8. 8. 2007 „Nouzové zásobování pitnou vodou", které upravuje postup kontroly jakosti pitné vody v mimořádné situaci a uvádí minimální nutné požadavky na jakost pitné vody v situacích, kdy není možné plně zajistit plnou aplikaci platných standardů.

\section{ZÁVĚR}

Pokud jsou splněny predpoklady uvedené v úvodu předchozí kapitoly, je poměrně dobrá pravděpodobnost, že obec bude mít své vodní zdroje v pořádku. Některé obce mají štěstí, že prírodní podmínky v jejich katastru zajistily dostatek kvalitní vody s nízkou zranitelností, takže i bez př́lišné péče o vodní zdroje mají dostatek dobré vody.

Jsou ale naopak i obce, které se setkávají s tak velkými problémy kolem zajištění zdrojů pitné vody, že na místní úrovni jsou - i v případě zájmu vedení obce - těžko řešitelné, a když ano, tak za neúnosné finanční a technické náročnosti. $V$ takovém prípadě je rozumné řešení spolehnout se na skupinový nebo oblastní vodovod, pokud je taková možnost. Jinak nezbývá, než aby obec našla potřebné finanční prostředky a za spolupráce príslušných odborníků se pokusila problém řešit, včetně vyhledání jiného lepšího zdroje vody na svém katastru, pokud ten stávající není dále použitelný.

Ne pro každou obec je tedy možná a rozumná cesta mít vlastní zdroj vody. $\checkmark$ prípadě, že ale obec svůj tradiční a kvalitní vodní zdroj má, není rozumné se ho zbavovat, naopak je třeba o něj pečovat, aby mohl sloužit i následujícím generacím. V tomto smyslu může být důležitost zachování místního zdroje pitné vody na podobné úrovni jako důležitost zachování školy, obchodu, kostela, zdravotnického střediska, historické památky nebo okolní prírody. Místní zdroj vody tak může být důležitou součástí sebeuvědomění venkovské komunity v rámci péče o svoji obec a krajinu, která je jejich domovem.

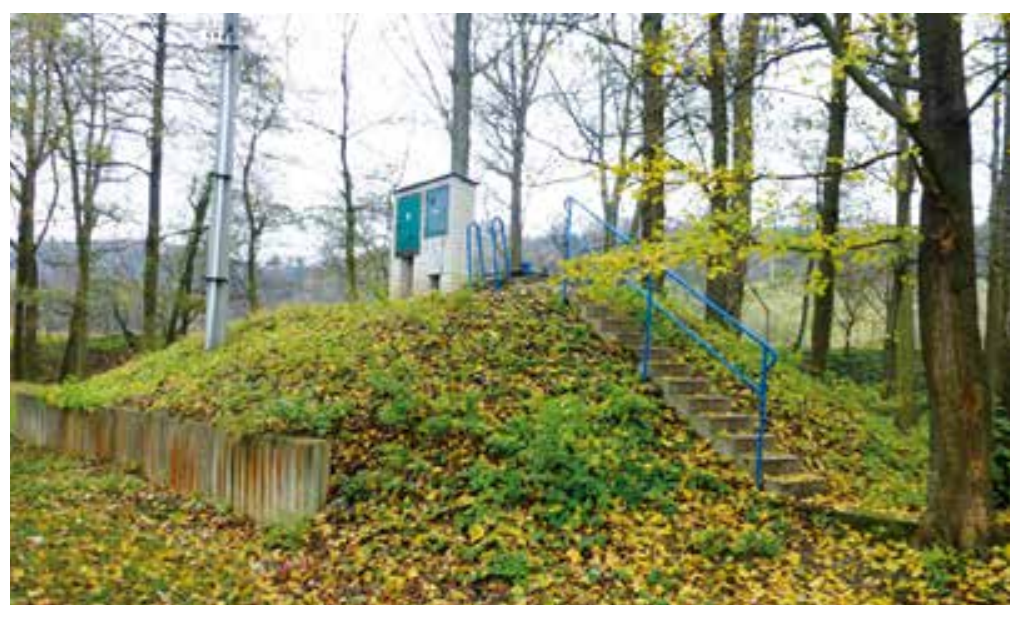

Vodní zdroj Radějov

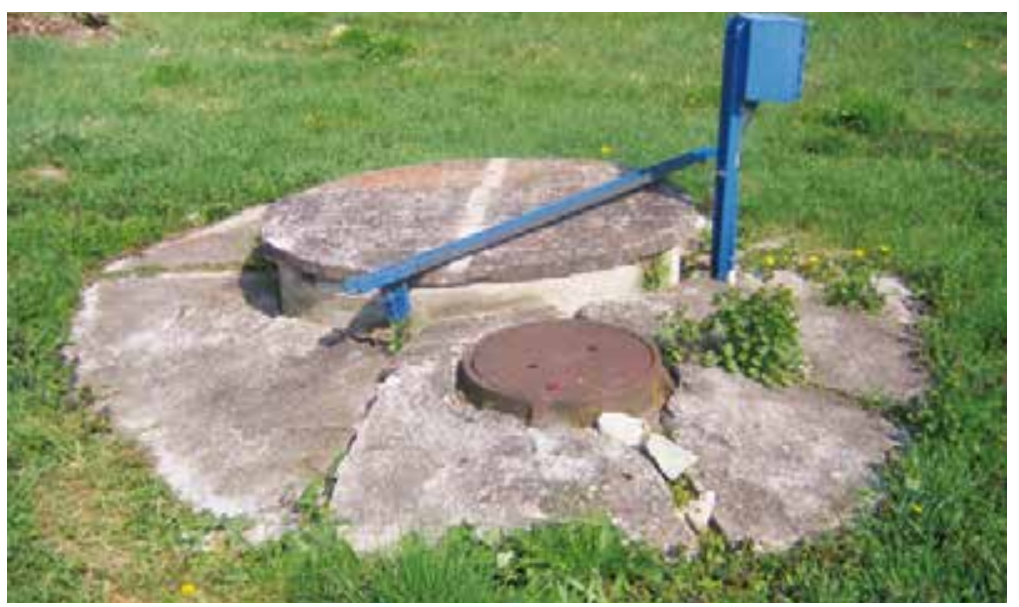

Jímací území Omice - zhlaví čerpací studny

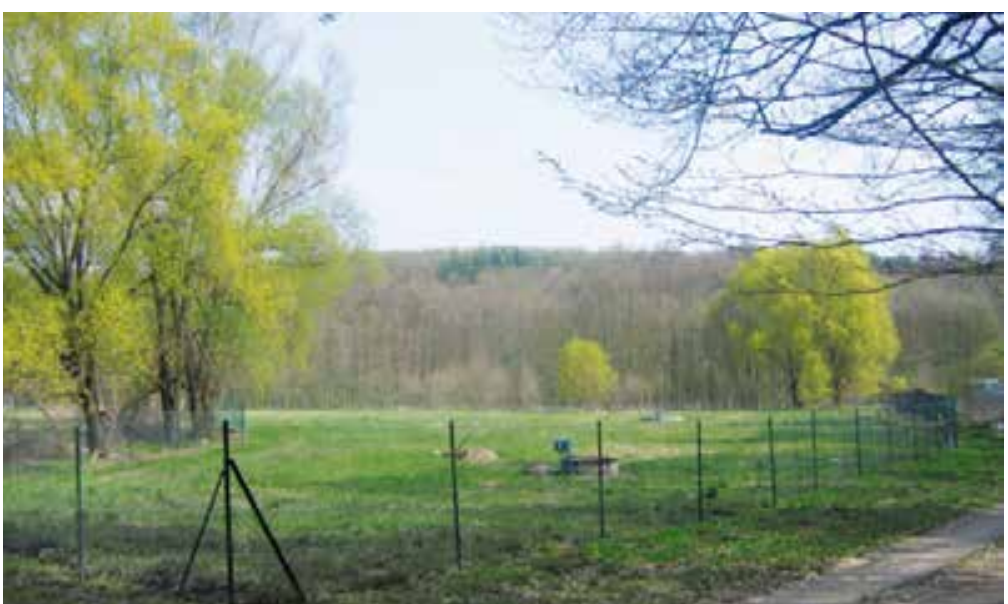

Jímací území Omice s oplocením ochranného pásma 1. stupně

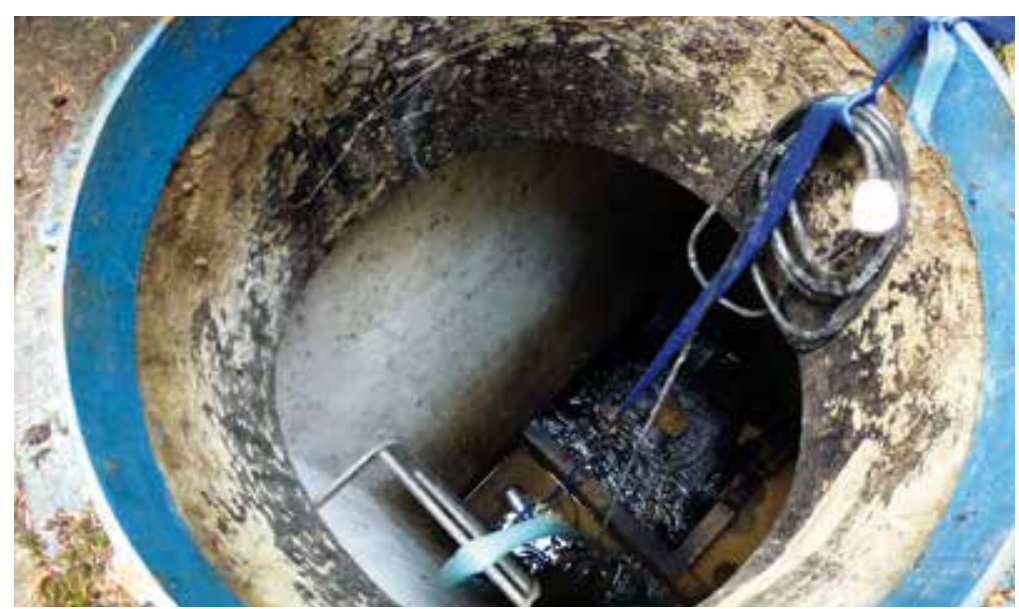

Velký Šenov - pohled do sběrné studny jímacího zářezu 


\section{Poděkování}

Príspěvek byl podpořen Technologickou agenturou ČR Č. TA02020184 Zajištěníjakosti pitné vody prì zásobování obyvatelstva malých obcíz mistních vodních zdrojü, který byl v letech 2012-2015 rešen ve Výzkumném ústavu vodohospodárském TGM, v. v. i., se společností GEOtest, a. s., a za spolupráce se Státním zdravotním ústavem.

\section{Literatura}

[1] GARI, D.W. a F. KOŽiŠEK. Zdravotni düsledky a rizika znečištěni pitnévody. Zpráva o kvalitě pitnévody v ČR. Odborná zpráva za rok 2011. Praha: Státní zdravotní ústav, 2012.

[2] KOŽíšEK, F. Problematika malých zdrojů pitné vody. Vodni hospodářství, 2011, 6, s. 225-227, ISSN 1211-0760.

[3] KOŽİ̌̌EKE, F., J. PAUL a J.V. DATEL. Zajištění kvality pitné vody príi zásobování obyvatelstva malými vodárenskými systémy. Praha: VÚV TGM, 2013, 114 s., ISBN 978-80-87402-26-9.

[4] TUHOVČÁK, L., J. RUČKA, F. KOŽí̌EK, P. PUMANN, J. HLAVÁČ, M. SVOBODA aj. Analýza rizik veřejných vodovodů. Brno: Akademické nakladatelství CERM, 2010, 254 s., ISBN 978-80-7204-676-8.

[5] DATEL, J.V., L. HARTLOVÁ, A. HRABÁNKOVÁ a J. NOVOTNÁ. Optimální zajištění jakosti pitné vody $\checkmark$ malých vodárenských systémech. Vodníhospodárství, 2014, 8, s. 1-4, ISSN 1211-0760.

[6] DATEL, J.V. aj. TA02020184 Zajištěni jakosti pitné vody prì zásobováni obyvatelstva malých obcíz mistních vodních zdrojü, Odborná zpráva o postupu pracía dosažených výsledcích za rok2012. MS. Praha: VúV TGM, 2013.

[7] DATEL, J.V. aj. TA02020184 Zajištěni jakosti pitné vody při zásobování obyvatelstva malých obci z mistních vodnich zdrojü, Odborná zpráva o postupu pracía dosažených výsledcich za rok 2013. MS. Praha: VúV TGM, 2014.

[8] DATEL, J.V. a HRABÁNKOVÁ, A. Specifika řizení a provozu malých vodních zdrojů. Sborník odborné konference Podzemní vody ve vodárenské praxi 2. Dolní Morava: Studio Axis, 2015.

[9] DATEL, J.V., L. HARTLOVÁ, A. HRABÁNKOVÁa J. NOVOTNÁ. Zajištění jakosti pitné vody při zásobování obyvatelstva malých obcí z místních vodních zdrojů. Vodni hospodárství, 2015, 12, s. 1-5, ISSN 1211-0760.

[10] DATEL, J.V., L. HARTLOVÁ, A. HRABÁNKOVÁ, Z. PIŠTORA, J. KUČERA, J. NOVOTNÁ a F. PASTUSZEK. Specifika provozu a ŕízení malých vodních zdrojů. Praha: VÚV TGM, 2015, 120 s., ISBN 978-80-87402-43-6.

\section{Autoři}

RNDr. Josef V. Datel, Ph.D.

凶josef_datel@vuv.cz

Ing. Anna Hrabánková

凶anna_hrabankova@vuv.cz

Výzkumný ústav vodohospodářský T. G. Masaryka, v. v. i.

Příspěvek prošel lektorským řízením.

\section{SPECIFICS OF LOCAL WATER RESOURCES IN SUPPLYING THE POPULATION WITH DRINKING WATER}

\section{DATEL, J. V.; HRABANKOVA, A.}

TGM Water Research Institute, p. r. i.

Keywords: drinking water - small water supply water quality - small municipalities

The paper summarizes the "Methodology for comprehensive management of small water resources to ensure optimal quality of drinking water in normal and emergency situations" that is a main result of the research project supported by the Technology Agency of the Czech Republic (TA 02020184). Quality of drinking water from small water sources - according to data of the Czech National Health Institute - has long been worse than water from larger water-supply networks. The finished methodology takes into account specific features of the management of small water resources, in order to ensure the good technical state and the optimal operation and protection. The main part of the methodology is a detailed form, understandable to non-experts, comfortable for collecting all necessary information about the water resource. The second part of the methodology involves technical evaluation processes of data collected and a design of measures to improve the situation. The final section deals with emergency supply of drinking water at the level of small municipalities. 